\title{
Defensins and Efflux Transporters Meet Their Fate in 2008: No Major Role in the Pathogenesis of Inflammatory Bowel Disease
}

\author{
Thomas Ochsenkühn \\ CED-Zentrum der Universität München - Klinikum Grosshadern, Medizinische Klinik II, München, Germany
}

In their paper, Heike Gutmann [1] and her colleagues from Basel, Switzerland, nicely tell the story of the rise and fall of a suspected candidate in inflammatory bowel disease (IBD) pathogenesis by demonstrating that the efflux transporters BCRP (breast cancer resistance protein) and P-gp (P-glycoprotein) play no major role in the pathogenesis of ulcerative colitis (UC).

Among other organs important for uptake and elimination of toxic substances, the intestine expresses BCRP and P-gp in the apical membrane of the enterocytes [2-6]. Previous genetic studies have reported that the P-gp and BCRP production is down-regulated in patients with active UC [7-10] and data indicated that their genetic locus is associated with a susceptibility for UC $[11,12]$. However, previous studies did not differentiate between the transporter expression in inflamed or unaffected mucosa and did not take into account whether the UC patients took anti-inflammatory medication. Therefore, Gutmann et al. [1] evaluated transporter expression in both unaffected and inflamed mucosa of patients with active UC, in drug-naive and treated patients with UC and compared the results to transporter expression in healthy subjects. They confirmed that P-gp and BCRP production is significantly reduced in the inflamed mucosa of treated and untreated patients with active UC, but they found that unaffected mucosa of UC patients showed no difference to healed mucosa of UC patients in remission and to mucosa of healthy controls. They concluded that the reason for a reduced protein production is very likely the inflammatory process per se.

Although not having received the same level of attention, efflux transporters now share their fate with the $\alpha$ defensins: a major role in the pathogenesis of IBD has been ruled out. In a recent publication in Gut, Lisa Simms [13] and her Australian colleagues had taken the $\alpha$-defensin story apart in a similar examination of a large series of more than 100 patients and controls with Crohn's disease or healthy guts. They showed that surface epithelial cells loss as a consequence of tissue damage by inflammation seems to be the main reason for the reduced protein expression of $\alpha$-defensins in patients with Crohn's disease. Gutmann and Simms have taught us that IBDs are more than an efflux transporter or defensin deficiency syndrome.

\section{KARGER}

Fax +4161306 1234 E-Mail karger@karger.ch www.karger.com
(C) 2008 S. Karger AG, Basel 0012-2823/08/0783-0152\$24.50/0

Accessible online at: www.karger.com/dig
PD Dr. med. Thomas Ochsenkühn, CED-Zentrum der Universität München

Klinikum Grosshadern, Medizinische Klinik II

Marchioninistrasse 15, DE-81377 München (Germany)

Tel. +49 897095 3014, Fax +49897095 5291

E-Mail thomas.ochsenkuehn@med.uni-muenchen.de 


\section{References}

1 Gutmann H, Hruz P, Zimmermann C, Straumann A, Terracciano L, Hammann F, Lehmann F, Beglinger C, Drewe J: Breast cancer resistance protein and P-glycoprotein expression in patients with newly diagnosed and therapy-refractory ulcerative colitis compared with healthy controls. Digestion 2008;78:154-162.

-2 Taipalensuu J, Tornblom H, Lindberg G, Einarsson C, Sjoqvist F, Melhus H, Garberg P, Sjostrom B, Lundgren B, Artursson P: Correlation of gene expression of ten drug efflux proteins of the ATP-binding cassette transporter family in normal human jejunum and in human intestinal epithelial Caco-2 cell monolayers. J Pharmacol Exp Ther 2001;299:164-170.

3 Zimmermann C, Gutmann H, Hruz P, Gutzwiller JP, Beglinger C, Drewe J: Mapping of multidrug resistance gene 1 and multidrug resistance-associated protein isoform 1 to 5 MRNA expression along the human intestinal tract. Drug Metab Dispos 2005;33:219224.

4 Maliepaard M, Scheffer GL, Faneyte IF, van Gastelen MA, Pijnenborg AC, Schinkel AH, van De Vijver MJ, Scheper RJ, Schellens JH: Subcellular localization and distribution of the breast cancer resistance protein transporter in normal human tissues. Cancer Res 2001;61:3458-3464.
5 Tanaka Y, Slitt AL, Leazer TM, Maher JM, Klaassen CD: Tissue distribution and hormonal regulation of the breast cancer resistance protein (BCRP/ABCG2) in rats and mice. Biochem Biophys Res Commun 2005; 326:181-187.

6 Mao Q, Unadkat JD: Role of the breast cancer resistance protein (ABCG2) in drug transport. AAPS J 2005;7:E118-E133.

7 Langmann T, Moehle C, Mauerer R, Scharl M, Liebisch G, Zahn A, Stremmel W, Schmitz $\mathrm{G}$ : Loss of detoxification in inflammatory bowel disease: dysregulation of pregnane $\mathrm{X}$ receptor target genes. Gastroenterology 2004; $127: 26-40$.

$>8$ Lawrance IC, Fiocchi C, Chakravarti S: Ulcerative colitis and Crohn's disease: distinc tive gene expression profiles and novel susceptibility candidate genes. Hum Mol Genet 2001;10:445-456.

-9 Englund G, Jacobson A, Rorsman F, Artursson P, Kindmark A, Rönnblom A: Efflux transporters in ulcerative colitis: decreased expression of BCRP (ABCG2) and PGP (ABCB1). Inflamm Bowel Dis 2007;13:291297.
10 Blokzijl H, Vander Borght S, Bok LI, Libbrecht L, Geuken M, van den Heuvel FA, Dijkstra G, Roskams TA, Moshage H, Jansen PL, Faber KN: Decreased glycoprotein (P-gp/ MDR1) expression in inflamed human intestinal epithelium is independent of PXR protein levels. Inflamm Bowel Dis 2007;13:710720 .

11 Schwab M, Schaeffeler E, Marx C, Fromm MF, Kaskas B, Metzler J, Stange E, Herfarth H, Schoelmerich J, Gregor M, Walker S, Cascorbi I, Roots I, Brinkmann U, Zanger UM, Eichelbaum M: Association between the C3435t MDR1 gene polymorphism and susceptibility for ulcerative colitis. Gastroenterology 2003;124:26-33.

12 Ho GT, Nimmo ER, Tenesa A, Fennell J, Drummond H, Mowat C, Arnott ID, Satsangi J: Allelic variations of the multidrug resistance gene determine susceptibility and disease behavior in ulcerative colitis. Gastroenterology 2005;128:288-296.

13 Simms LA, Doecke JD, Walsh MD, Huang N, Fowler EV, Radford-Smith GL: Reduced $\alpha$ defensin expression is associated with inflammation and not NOD2 mutation status in ileal Crohn's disease: Gut 2008;57:903910 . 